\title{
Effect of Castration on Some Physiological Aspect in Rats: Effect of Testosterone Hormone
}

\author{
A. A. Hassan \\ Department of physiology / College of Veterinary Medicine \\ University of Mosul
}

Received

03 / 05 / 2009
Accepted

15 / 07 / 2009

\section{الخلصة}

لجريت الدرلسة لمعرف ة دور عملي ة لستئ صل الخ صى والتع -ويض بهربه -ون

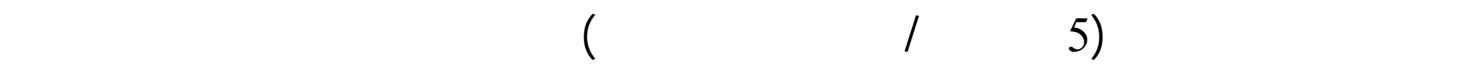

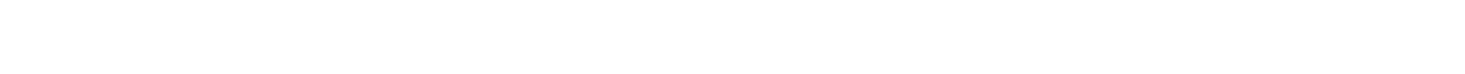

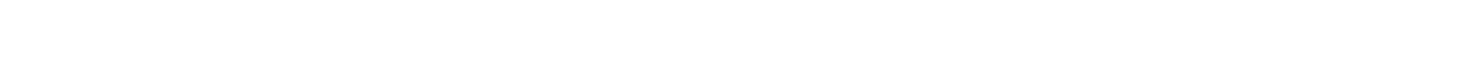

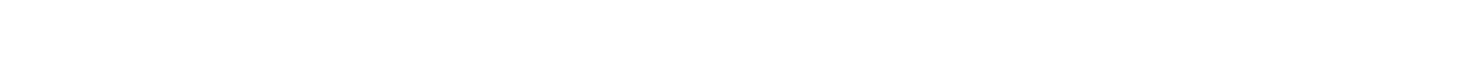

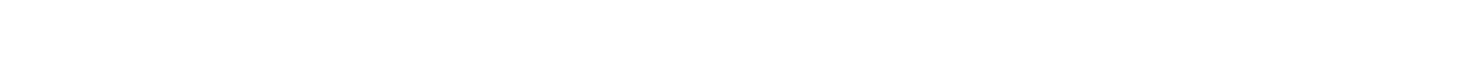

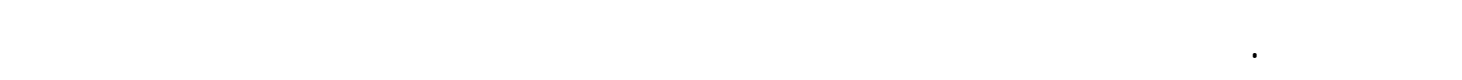

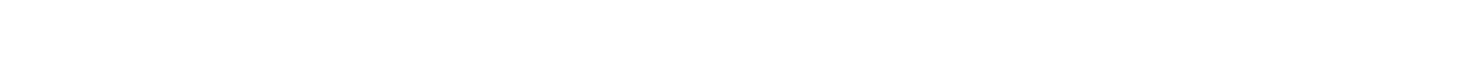

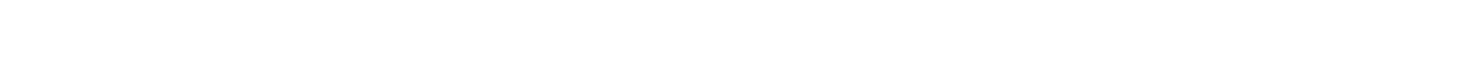

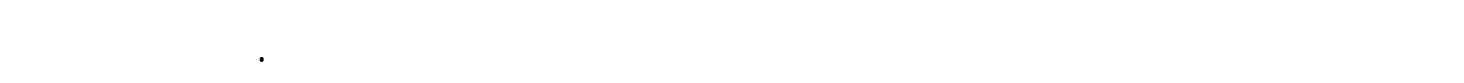

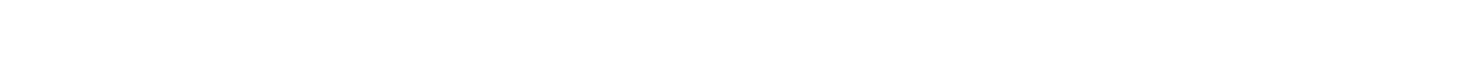

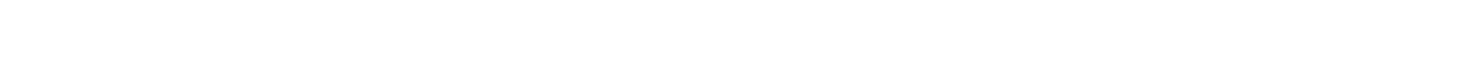

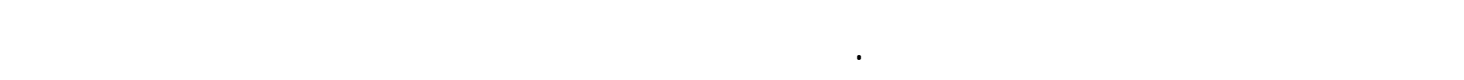

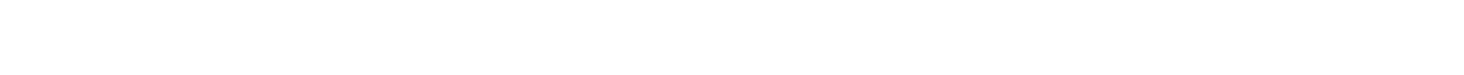

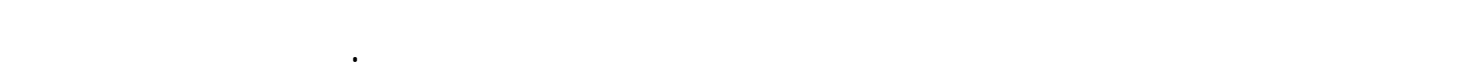

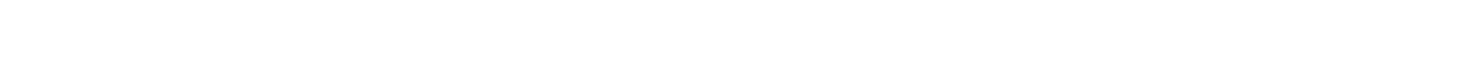

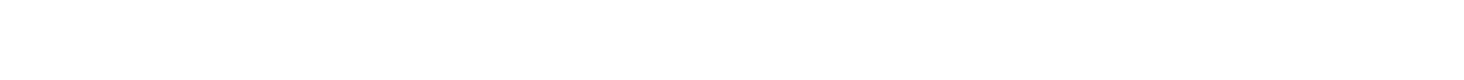

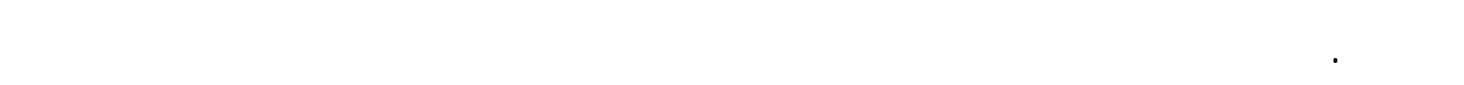

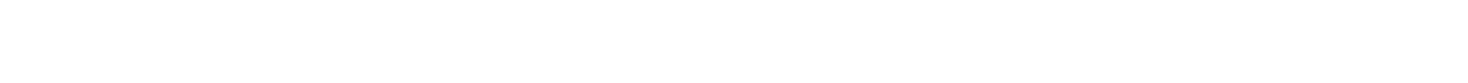


والكلوبيولين وللسكر وفعالية أنزيم الالنين لمينوترلنفيريز ووزن الجم. وقد لمد تتنج م ن

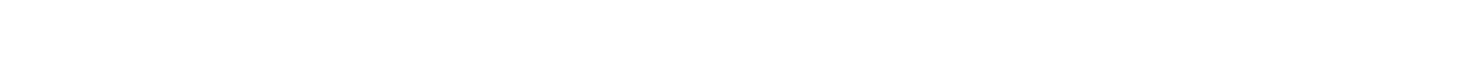

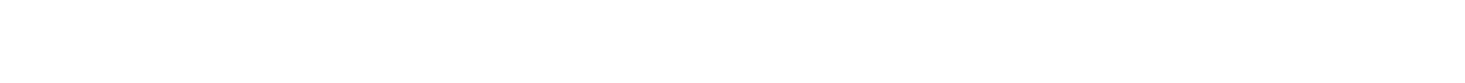
سببها عملية لستئصل الخصو.

\begin{abstract}
This study provides novel information on the role of castration and testosterone hormone replacement at $(5 \mathrm{ng} / \mathrm{kg} \mathrm{B}$. Wt.) in rats in the parameters each of red blood corpuscles count, hemoglobin concentration, packed cell volume (PCV), erythrocytes indexes, total leucocytes count, differential leucocytes count, total cholesterol, triglyceride, low density lipoprotein, high density lipoprotein, alanine aminotransferase enzyme activity, total proteins, albumin, globulin, glucose and body weight parameters in rats. Castration of the rats caused a significant decrease in red blood corpuscles, hemoglobin concentration and packed cell volume; accompanied with significant increased mean corpuscular volume, mean corpuscular hemoglobin, total number of leucocytes, and percentage of neutrophils and low percentage of lymphocytes compared with control group. Treatment with testosterone hormone caused significant increased in red blood corpuscles, hemoglobin concentration and packed cells volume and significant decreased in total number of leucocytes, neutrophils and increased in the number of lymphocytes. The present study showed a significant increase in the levels of total cholesterol, triglycerides, low density lipoprotein in castrated rats group compared with control value. Administration of testosterone hormone caused significant decreased in the levels of total cholesterol, triglycerides, and low density lipoproteins compared with castrated rats group. The current study showed no significant differences between groups in mean corpuscular hemoglobin concentration, high density lipoproteins, total protein, albumin, globulin, glucose, alanine aminotrasferase enzyme activity and body weights. We concluded from this study that castration of the rats produced significant effects in certain blood constituent and lipid profile. Moreover administration of testosterone hormone reversed the adversed effects caused by castration.
\end{abstract}

Keywords: castration, rats, blood picture, lipid profile, testosterone hormone replacement.

\title{
Introduction
}

Castration is removal of testis, or testicles, of male animals, farm animals have been castrated to eliminate breeding and reduce aggressive behavior (1). In the adult, red blood corpuscles, white blood cells, and 
blood platelets are formed in the bone marrow, in the fetus, blood cells are also formed in the liver and spleen (2). The relationship between the endocrine system and hemopoiesis has been known for more than half a century, hypopituitarism is often accompanied by normochromic and normocytic anemia. Androgen and thyroid hormones are known to stimulate erythropoiesis (3). Erythropoietin is secreted mainly from the peritubular endothelia and interstitial fibroblasts of renal tubules. It is also secreted partly from the liver in fetal rats and sheep, placenta, and astrocytes in the brain. The liver is the primary site of erythropoietin production in the fetus, and extrarenal erythropoietin production was increased in anemic rats. In adult rats, erythropoietin is secreted mainly from the kidney, suggesting that some mechanism switches erythropoitin secretion from the liver to the kidney. This functional switching mechanism has yet to be fully elucidated. Fetal hypoxemia experiments showed that the erythropoitin secretion from the placenta was increased by hypoxic stimuli (4). Testosterone hormone is the principal androgen secreted by Leydig cells. It exerts both androgenic effects involving growth stimulation and functional maintenance of the male reproductive tract and anabolic effects involving growth stimulation of nonreproductive organs, such as muscle, kidney, liver, and submaxillary salivary glands (5). This natural androgen is both 5a-reduced to dehydroepiandrosterone (DHT), a potent androgen that binds with high affinity to androgen receptor (AR), and aromatized to estrogen (5). In hypogonadal or aging men with clinical symptoms suggestive of androgen deficiency and reduced the testosterone level in serum, testosterone replacement therapy has successfully alleviated symptoms.

To what extent these effects are mediated directly through testosterone or through conversion to DHT or17ß-estradiol $\left(\mathrm{E}_{2}\right)$ has not been clearly delineated (5). Leblanc et al (6) suggest that both androgens and estrogens are important, but differential, regulators of lipid metabolism (6). Also suggest that quantities as well as the relative proportion of androgens and estrogens are important factor in the regulation of the plasma lipid profile, both androgen and estrogen deprivations are probably responsible for the unfavorable lipid profile in the castrated animals. It is, in fact, known that dehydroepiandrosterone (DHEA) is mainly transformed into androgens in the peripheral tissues in the rat (7). The physiological effects of sex steroids hormone on peripheral tissues are mediated though both intracrine and classical endocrine pathways (6).

Furthermore, it should be recalled that exogenous or endogenous testosterone reaches the androgen receptor usually after conversion into dihydrotestosterone (dht) in specific target tissues, whereas the same steroid can also act as an estrogen precursor when transformed by aromatase (5). In animal subjected to orchiectomy, varying degree of 
hypertrophy have often been observed, even involving non-reproductive organs, Liver hypertrophy appear particularly interesting in view of the metabolic alterations that's could possible ensue (8). The effects of castration were revealed by a reduction of the volume of hepatocytes associated with a reduction of the sinusoidal bed. Such reduction is corresponding associated with an increase of extrapranchymal components (endothelia Glisson capsule) (8). Other study demonstrated that in male rats long term castration causes an increase in sensitivity to estradiol as measured by induction of progesterone receptor m-RNA (PRmRNA) in ventromedial hypothalamus (VMH) (9). Low plasma testosterone levels are associated with hyperinsulinemia and glucose intolerance (10).

The present study was designed to investigate the effect of castration and testosterone hormone replacement on hematological \& some biochemical parameter, in rats.

\section{Materials and method}

Preparation of animals:

Eighteen postnatal male albino rats were obtained from the animals house of Veterinary College-University of Mosul at one month of age weighing $(30-35 \mathrm{~g})$. They were housed in polypropylene cages under controlled conditions of temperature $\left(20-25 \mathrm{c}^{\circ}\right)$ and lighting (12hours light $/ 12$ hours dark).The rats supplied diet and tap water ad libitum.

Experimental design:

Rats at one month age were randomly divided into three groups of (6 animals/ group). Group1: intact control rats received oil vehicle at age of two month, (for one month), whereas group 2: animals at one month bilaterally surgically removed the testis under ketamine hydrochloride $(50 \mathrm{mg} / \mathrm{kg}$ B. Wt). (Ketalar-Park Davis Company U.K.) and xylazine $(5 \mathrm{mg} / \mathrm{kg} \mathrm{B}$. Wt.). (Ceva Sante animal - Xylazine France) anesthesia given intraperitonium. Using sterile instruments and gloves. A transverse scrotal incision was made, testicles exposed, and removed. The scrotal incision was then closed using simple stitch. Rats were placed in clean cages and monitored until fully recovered from the effect of anesthesia.

Group 3: animals at one month bilaterally surgically removed the testis and after one month of castration rats treated with testosterone hormone (5 ng/ $\mathrm{kg}$ B. Wt) (N V Organon Oss Holand) (11). subcutaneously injection (volume of injection $0.2 \mathrm{ml}$ ) for one month. At the end of experiment blood sample collected from the cornea of eye into tubes contain anticoagulant (EDTA) for complete blood picture tests, also blood sample were collected into clean dry centrifuge tubes allowed to clot, serum separated after centrifugation at $1500 \mathrm{rpm}$ for (15 minute) (12). 
Complete blood picture

- Red blood corpuscles count: They were counted per cubic millimeter of blood by hemocytometer; blood was diluted with haym's solution.

- White blood cell count: They were counted per cubic millimeter of blood by hemocytometer; blood was diluted with turk 's solution.

- Hemoglobin concentration: it determined by Sahli method $20 \mu 1$ of blood added to graduated tube contain $(0.1 \mathrm{~N}) \mathrm{Hcl}$, blood and $\mathrm{Hcl}$ mixed and after10 minutes, distilled water added gradually until the color of the mixture become identical to standard of the comparator block, the hemoglobin value is obtain (13).

- Packed Cell Volume: determined by microhematocrite capillary tube and microhematocrite centrifuge (1200 circle/minute) (13).

- MCV, MCH and MCHC were calculated as described by (14).

- Differential leucocytes count (DLC): thin blood film was prepared and stained with Wright stain (12), and counted 100 cell using Battlement method, calculated the percentage number of each of lymphocyte, neutrophil, basophil, eosinophil and monocyte.

Biochemical analysis: Total cholesterol, high density lipoprotein, glucose, alanine aminotransferase enzyme activity and albumin were measured using colorimetric assay kit (Syrbio, Syria). Triglyceride was measured using kit (bioMerieux, France). Total protein (Biuret method) (15).

Statistical analyses:

All data were analyzed by one-way analysis of variance. The specific group differences were determined using Duncan multiple range test (16). The accepted level of significant was $(p \leq 0.05)$.

\section{Results}

In present study Table 1- demonstrated that significant decreased $(\mathrm{p} \leq 0.05)$ in the red blood corpuscles count, hemoglobin concentration and packed cells volume and increased in white blood cells count in castrated group compared with control value. The group of testosteroneadministered to the castrated rats showed a significant increased $(\mathrm{p} \leq 0.05)$ in red blood cells, hemoglobin concentration and packed cells volume, furthermore decreased in white blood cells compared with castrated group and retuned the red blood corpuscles and hemoglobin concentration to the control value.

Table 2- showed significant increased $(p \leq 0.05)$ mean corpuscular volume, mean corpuscular hemoglobin with no difference in mean corpuscular hemoglobin concentration. Treatment the castrated rats with testosterone hormone showed no significant differences in mean corpuscular volume and mean corpuscular hemoglobin concentration. But caused significant decreased $(\mathrm{p} \leq 0.05)$ in mean corpuscular hemoglobin compared with castrated group. The current of study revealed no significant changes between groups in body weight. 
Table 1: Effect of castration in the red blood count, haemoglobin concentration, packed cells volume and white blood cell count on rats: effect of testosterone hormone replacement.

\begin{tabular}{||l|c|c|c|c||}
\hline \hline Treatment & $\begin{array}{c}\text { Red blood } \\
\text { corpuscles } \\
10^{6} \times\end{array}$ & $\begin{array}{c}\text { Hemoglobin } \\
(\mathrm{g} / \mathrm{dl})\end{array}$ & $\begin{array}{c}\text { Packed cell } \\
\text { volume } \%\end{array}$ & $\begin{array}{c}\text { White blood } \\
\text { cells } \times 10^{3}\end{array}$ \\
\hline \hline Control & $\begin{array}{c}\mathrm{a} \\
6.29 \pm 0.24\end{array}$ & $\begin{array}{c}\mathrm{a} \\
12.1 \pm 0.44\end{array}$ & $\begin{array}{c}\mathrm{b} \\
29.3 \pm 1.22\end{array}$ & $\begin{array}{c}\mathrm{c} \\
5.71 \pm 0.20\end{array}$ \\
\hline castrated rats & $\mathrm{b}$ & $\mathrm{b}$ & $\mathrm{c}$ & $\mathrm{a}$ \\
$9.90 \pm 0.14$ & $9.5 \pm 0.19$ & $23.3 \pm 0.55$ & $8.27 \pm 0.21$ \\
\hline $\begin{array}{l}\text { Castrated rats }+ \\
\text { Testosterone }(5 \mathrm{ng} \\
\text { /kgB.W) }\end{array}$ & $\begin{array}{c}\mathrm{a} \\
6.48 \pm 0.23\end{array}$ & $\begin{array}{c}\mathrm{a} \\
13.1 \pm 0.26\end{array}$ & $\begin{array}{c}\mathrm{a} \\
34.83 \pm .9\end{array}$ & $\begin{array}{c}\mathrm{b} \\
7.37 \pm 0.34\end{array}$ \\
\hline \hline
\end{tabular}

- Values were expressed as means \pm SE from 6 rats /group.

- Values with different letters are significantly different at $(p \leq 0.05)$.

Table 2: Effect of castration in erythrocyte indices and body weight on rats :effect of testosterone hormone replacement.

\begin{tabular}{||c|c|c|c|c||}
\hline \hline Treatment & $\mathrm{MCV}(\mathrm{fl})$ & $\mathrm{MCH}(\mathrm{pg})$ & $\mathrm{MCHC}(\mathrm{g} / \mathrm{d})$ & $\begin{array}{c}\text { Body } \\
\text { weight }(\mathrm{g})\end{array}$ \\
\hline \hline Control & $\begin{array}{c}\mathrm{b} \\
47.17 \pm 3.43\end{array}$ & $\begin{array}{c}\mathrm{b} \\
20.82 \pm 1.48\end{array}$ & $\begin{array}{c}\mathrm{a} \\
43.75 \pm 3.27\end{array}$ & $\begin{array}{c}\mathrm{a} \\
200.5 \pm 6.14\end{array}$ \\
\hline castrated rats & $\mathrm{a}$ & $\mathrm{a}$ & $\mathrm{a}$ & $\mathrm{a}$ \\
$20.04 \pm 4.82$ & $24.58 \pm 1.12$ & $40.99 \pm 1.55$ & $201.1 \pm 5.32$ \\
\hline $\begin{array}{c}\text { Castrated rats }+ \\
\text { Testosterone } \\
(5 n g / \mathrm{kg} \text { B W) }\end{array}$ & $\begin{array}{c}\mathrm{ab} \\
53.94 \pm 1.75\end{array}$ & $\begin{array}{c}\mathrm{b} \\
20.28 \pm 0.85\end{array}$ & $\begin{array}{c}\mathrm{a} \\
\mathrm{a}\end{array}$ \\
\hline \hline
\end{tabular}

- Values were expressed as means \pm SE from 6 rats /group.

- Values with different letters are significantly different at $(\mathbf{p} \leq \mathbf{0 . 0 5})$.

In current study Table 3- revealed a significant increased $(\mathrm{p} \leq 0.05)$ in the percentage number of neutrophils accompanied with significant decreased $(\mathrm{p} \leq 0.05)$ in the percentage number of lymphocyte in castrated group. Testosterone-administered to the castrated rats reversed these effects and return the value to control, accompanied with no changes between groups in basophiles, eosinophils and monocytes count. 


\section{A. A. Hassan}

Table 3: Effect of castration in differential count of leukocytes in rats: effect of testosterone hormone replacement.

\begin{tabular}{|c|c|c|c|c|c|}
\hline Treatment & $\begin{array}{c}\text { Neutrophil } \\
\%\end{array}$ & $\begin{array}{c}\text { Lymphocyte } \\
\%\end{array}$ & $\begin{array}{c}\text { Basophile } \\
\%\end{array}$ & $\begin{array}{c}\text { Eosinophil } \\
\%\end{array}$ & $\begin{array}{c}\text { Monocyte } \\
\%\end{array}$ \\
\hline Control & $\begin{array}{c}\mathrm{b} \\
70.16 \pm 0.5\end{array}$ & $\begin{array}{c}\mathrm{a} \\
28.66 \pm 0.4\end{array}$ & $\begin{array}{c}\mathrm{a} \\
0.33 \pm 0.2\end{array}$ & $\begin{array}{c}\mathrm{a} \\
0.33 \pm 0.2\end{array}$ & $\begin{array}{c}\mathrm{a} \\
0.33^{2}\end{array}$ \\
\hline castrated rats & $\begin{array}{c}\mathrm{a} \\
78.83 \pm 1.4\end{array}$ & $\begin{array}{c}\mathrm{b} \\
21.0 \pm 1.8\end{array}$ & $\begin{array}{c}\mathrm{a} \\
0.50 \pm 0.2\end{array}$ & $\begin{array}{c}\mathrm{a} \\
0.50 \pm 0.2\end{array}$ & $\begin{array}{c}\mathrm{a} \\
0.50 \pm 0.2\end{array}$ \\
\hline $\begin{array}{c}\text { Castrated rats }+ \\
\text { Testosterone } \\
(5 \mathrm{ng} / \mathrm{kg} \mathrm{B} \mathrm{W})\end{array}$ & $\begin{array}{c}\mathrm{b} \\
68 \pm 0.9\end{array}$ & $\begin{array}{c}\mathrm{a} \\
30.33 \pm 0.8\end{array}$ & $\begin{array}{c}\mathrm{a} \\
0.50 \pm 0.2\end{array}$ & $\begin{array}{c}\mathrm{a} \\
0.50 \pm 0.2\end{array}$ & $\begin{array}{c}\mathrm{a} \\
0.66 \pm 0.2\end{array}$ \\
\hline
\end{tabular}

- Values were expressed as means $\pm \mathrm{SE}$ from 6 rats /group.

- Values with different letters are significantly different at $(\mathbf{p} \leq 0.05)$.

Table (4). Demonstrated a significant increased $(p \leq 0.05)$ in the levels of total cholesterol, triglyceride and low density lipoprotein with no difference in high density lipoproteins in castrated rats group compared with control value. The group of testosterone-administered to the castrated rats showed a significant decreased $(\mathrm{p} \leq 0.05)$ in total cholesterol, triglyceride and low density lipoproteins, accompanied with no significant change in high density lipoproteins compared with castrated group.

Table (5). Demonstrated no significant changes between control, castrated, testosterone replacement groups in the levels of total protein, albumin, globulin, alanine aminotransferase enzyme activity and glucose.

Table 4: Effect of castration in cholesterol, triglyceride, high density lipoproteins, and low density lipoproteins on rats: effect of testosterone hormone replacement.

\begin{tabular}{|c|c|c|c|c|}
\hline Treatment & $\begin{array}{l}\text { Cholesterol } \\
\mathrm{mg} / \mathrm{dl}\end{array}$ & $\begin{array}{l}\text { Triglyceride } \\
\text { mg/dl }\end{array}$ & $\begin{array}{c}\text { High density } \\
\text { Lipoproteins } \\
\text { mg/dl } \\
\end{array}$ & $\begin{array}{c}\text { Low density } \\
\text { Lipoproteins } \\
\mathrm{mg} / \mathrm{dl}\end{array}$ \\
\hline Control & $\begin{array}{c}\mathrm{b} \\
84.91 \pm 2.16\end{array}$ & $\begin{array}{c}\mathrm{b} \\
102.08 \pm 3.98\end{array}$ & $\begin{array}{c}\mathrm{b} \\
49.35 \pm 0.56\end{array}$ & $\frac{\mathrm{a}}{15.23 \pm 1.48}$ \\
\hline castrated rats & $\frac{\mathrm{a}}{101.88 \pm 1.41}$ & $\frac{\mathrm{a}}{121.88 \pm 2.78}$ & $\begin{array}{c}\mathrm{ab} \\
46.28 \pm 2.12\end{array}$ & $\begin{array}{c}c \\
31 \pm 1.66\end{array}$ \\
\hline $\begin{array}{c}\text { Castrated rats }+ \\
\text { Testosterone } \\
(5 \mathrm{ng} / \mathrm{kg}\end{array}$ & $\begin{array}{c}\mathrm{b} \\
82.93 \pm 2.55\end{array}$ & $\begin{array}{c}\mathrm{b} \\
97.01 \pm 2.58\end{array}$ & $\begin{array}{c}b \\
41.43 \pm 2.14\end{array}$ & $\begin{array}{c}\mathrm{b} \\
22.12 \pm 1.55\end{array}$ \\
\hline
\end{tabular}

- Values were expressed as means $\pm \mathrm{SE}$ from 6 rats /group.

- Values with different letters are significantly different $(p \leq 0.05)$. 
Table 5: Effect of castration in total proteins, albumin, globulin glucose, alanine aminotransferase enzyme activity, on rats: effect of testosterone hormone

replacement.

\begin{tabular}{|c|c|c|c|c|c|}
\hline Treatment & $\begin{array}{l}\text { Total } \\
\text { protein } \\
\mathrm{g} / \mathrm{dl}\end{array}$ & $\begin{array}{l}\text { Albumin } \\
\mathrm{g} / \mathrm{dl}\end{array}$ & $\begin{array}{l}\text { Globulin } \\
\mathrm{g} / \mathrm{dl}\end{array}$ & $\begin{array}{c}\text { Alanine } \\
\text { Amimotraferase } \\
\text { Unit/L }\end{array}$ & $\begin{array}{l}\text { Glucose } \\
\text { g/dl }\end{array}$ \\
\hline Control & $\begin{array}{c}a \\
7.31 \pm 0.39\end{array}$ & $\begin{array}{c}\mathrm{a} \\
4.55 \pm 0.44\end{array}$ & $\begin{array}{c}a \\
2.76 \pm 0.22\end{array}$ & $\begin{array}{c}\mathrm{a} \\
48.06 \pm 0.75\end{array}$ & $\begin{array}{c}\mathrm{a} \\
88.46 \pm 2.73\end{array}$ \\
\hline castrated rats & $\begin{array}{c}\mathrm{a} \\
6.38 \pm 0.28\end{array}$ & $\begin{array}{c}\mathrm{a} \\
3.76 \pm 0.14\end{array}$ & $\begin{array}{c}\mathrm{a} \\
2.61 \pm 0.30\end{array}$ & $\begin{array}{c}\mathrm{a} \\
51.83 \pm 1.35\end{array}$ & $\begin{array}{c}\mathrm{a} \\
94.41 \pm 4.51\end{array}$ \\
\hline $\begin{array}{l}\text { Castrated rats }+ \\
\text { Testosterone } \\
(5 n g / k g)\end{array}$ & $\begin{array}{c}\mathrm{a} \\
6.68 \pm 0.57\end{array}$ & $\begin{array}{c}\mathrm{a} \\
3.63 \pm 0.36\end{array}$ & $\begin{array}{c}\mathrm{a} \\
3.63 \pm 0.36\end{array}$ & $\begin{array}{c}\mathrm{a} \\
48.51 \pm 2.19\end{array}$ & $\begin{array}{c}\mathrm{a} \\
99.67 \pm 3.57\end{array}$ \\
\hline
\end{tabular}

- Values were expressed as means $\pm \mathrm{SE}$ from 6 rats /group.

- Values with different letters are significantly different $(p \leq 0.05)$.

\section{Discussion}

The results of present study showed, castration of the rats caused a significant decreased in red blood corpuscles count, hemoglobin concentration and paked cell volume, moreover significant increased in mean corpuscular volume and mean corpuscular hemoglobin. All these parameters were reversed by testosterone replacement. This finding therefore corroborates similar findings reported by Kelani et al (17). Testosterone has the ability to increase erythropoiesis (red blood corpuscles production) in the kidneys, and a higher red blood corpuscles (RBCs) count may improved iron kinetic studies.

The explanation of these results are castration of the animals caused minimum osmotic fragility (17). Testosterone may affect certain factor which predispose red blood corpuscles membranes to osmotic lysis such factors include reduction in red blood corpuscles ATP concentration, which invariably affects the ATP-motivated $\mathrm{Na}^{+}-\mathrm{K}^{+}$pump of the erythrocyte membrane, reduction in the enzymes involved in phosphate dehydrogenase and changes in the red blood cell membrane lipid content. All of these invariably affected the density, and subsequently the osmotic fragility, of red blood cells membrane (17).

The current study revealed a significant increase in total number of white blood cells and percentage number of neutrophils and lowing lymphocyte number. This result seems to agree with that reported by Murata et al (18), Pang (19) and Stafford (1) in castrated bull.

Castration has been shown to elicit physiological stress, inflammatory reactions, pain-associated behavior, suppression of immune function, and a reduction in performance to varying degrees $(20,21)$. Castration causes increased hepatoglobin and decreased gamma- 
interferon exerts a suppressive effect on lymphocyte function, and reduction of gamma suppression of the immune system "cell -mediated immunity", also castration-induced suppression of interferon-gamma and increases in neutrophil numbers and the neutrophil :lymphocyte ratio(22). Or the possible increased in the white blood cells count which was accounted for mainly by changes in the number of neutrophils.

Androgens exert potent regulatory influence over the immune system, although the full nature of these effects and mechanism underlying hormone-induced changes in host immunity are poorly understood. Several observations indicate that sex hormones serve as important regulators of lymphopoisis. Thymic involution that occurs during puberty is associated with the onset of sex hormone production and can be delayed by castration prior to puberty $(23,24)$. Castration of mice after puberty reverses thymic involution and leads to thymic hypertrophy, a process that can be reversed by replacement of androgen or estrogen (23). The production of B lymphocyte is regulated by physiologic level of androgens (24).

The current study showed that the elimination of testicular androgens by castration results in a significant increase total cholesterol, triglyceride and low density lipoprotein. this result agree with Goldberg et al and Casquero et al $(25,26)$, these results suggest that the increase in plasma LDL is due to an increase in the number of LDL particles. (26) Revealed that, castrated mice had an increase in the LDL fraction, whereas the HDL fraction was reduced. several studies have reported that castration in prostate cancer results in an unfavorable lipid profile, namely in increase in total cholesterol, LDL-C $(27,28)$. The increase in the number of LDL particles in the present study could result from reduction LDL uptake by the LDL receptor $(28,29)$.

One could argue that alteration in the plasma lipoprotein profile after castration could be the result to an increase in the secretion of hepatic very low density lipoprotein VLDL of cholesterol. Circulating VLDL particles are then catabolized into LDL cholesterol particles by the action of lipoprotein lipase (LPL). Furthermore, direct hepatic secretion of LDL in castration animals could explain the increase levels of plasma LDL, even through this metabolic pathway is not a major contributor to circulating LDL particles in normal animals. Androgen through surgical castration results in an atherogenic lipid profile (30).

It is also remarkable that after castration, intratissular androgens could possibly favor their antagonistic effect on the action of estrogens on LDL receptor expression (6).

\section{Acknowledgements:}

This study was supported by the College of Veterinary Medicine, University of Mosul. 


\section{References}

1) Stafford K. J. Alleviating the pain caused by the castration of cattle. Vet. J., 173:333-342 (2007).

2) Ganong W. F., "Review of Medical Physiology" Appleton \& Longe (2006).

3) Sohmiya $M$ and Kato $Y$. Human growth hormone and insulin-like growth factor-I inhibit erythropoietin secretion from the kidneys of adult rats. J. Endocrinol., 184, 199-207 (2005).

4) Davis L. E., Widness J.A and Brace R. A. Renal and placental secretion of erythropoietin during anemia or hypoxia in the ovine fetus. Am. J. Obst. Gynecol., 189: 1764-1770 ( 2003).

5) Barbara J., Attardi Sheri A Hild and Jerry R Reel. A New potent orally active androgen with progestational activity. Endocrinology, 147: (6) 3016-3026(2006).

6) Leblanc M., Bélanger M., Julien P., Tchernof A., Labrie C., Bélanger $\mathrm{M}$ and Labrie F. Plasma lipoprotein profile in the male cynomolgus monkey under normal hypogonadal and combined androgen blockade conditions. J. Clin. Endocrinol. Metab., 89: (4)1849-1857 (2004).

7) Sourla A., Martel C., Labrie $\mathrm{C}$ and Labrie F. Almost exclusive androgenic action of dehydroepiandrosterne in rat mammary gland. Endocrinology, 139:753-764. (1998).

8) Vizzotto L., Dolci C., Pandolfi M., Pizzichini M and Marinello E. Morphometric evaluation of rat liver after castration: effect of testosterone. Int J Tissue React., 17 : (2)73-79 (1995).

9) Wennstrom K. L. and Crews D. Effect of long-term castration and long-term androgen treatment on sexually dimorphic estrogeninducible progesterone receptor Mrna levels in the ventomedial hypothalamus of whiptail lizards. Hormone and Behavior., 34:11-16 (1998).

10) Tchernof A., Labrie F., Belanger A., Prud home J. P., Bouchard C., Tremblay A., Nadeau A and Despre J.P. Relationships between endogenous steroid hormone globulin and lipoprotein levels in men: contribution of visceral obesity, insulin levels and other metabolic variables. Atherosclerosis 133 :(2)235-244 (1997).

11) Gans S. and Erskine M. S. Effects of neonatal testosterone treatment on pacing behaviors and development of conditioned place preference. Horm. Behav., 44(4):345-364(2003). 
12) Fox J. G. Cohen B. J and Loew F. M. "Laboratory Animal Medicine" Academic Press London, U.K. 19-20 (1984).

13) Jain N. C ED. "Schalm's Veterinary Hematology" USA. Lea and Febiger. 276-282 (1986).

14) Schalm O. W., Lain N. C and Carrol E. I. "Veterinary Hematology" $34^{\text {th }}$ Ed; Lea and Febiger Philadelphia Pennsylvania (1975).

15) Ainbender E., Weisinger. Hevizy R. B and Hodes M. L. Difference in the immunoglobulin class of polio antibody in the serum of men and women. J.Immunol., 101:92(1968).

16) Petrie $A$ and Watson $P$. "Statistic for Veterinary and Animal Science" Blackwell Publishing Company (1999).

17) Kelani O. L and Durotoye L. A. Haematological responses of the African giant rat (Cricetomis gambianus) to castration and androgen replacement. Vetreinarski Arhiv., 72(1)39-49 (2002).

18) Murata $H$. Effects of Burdizzo castration on peripheral blood lymphocyte parameters in calves. Vet. J., 153:229-231 (1997).

19) Pang W. Y. Earley B.T. Sweeney T. M. A. Crowe M. A. Effect of carprofen administration during banding or burdizzo castration of bulls on plasma cortisol, in vitro interferon-production, acute-phase proteins, feed intake, and growth. J. Anim. Scie., 84; 351-359(2006).

20) Molony V., Kent J. E and Robertson I. S. Assessment of acute and chronic pain after different methods of castration of calves. App. An. Beh. Sci., 46:33-48(1995).

21) Fisher A. D., Crowe M. A and Alonso de la Varga ME. Effect of castration method and the provision of local anesthesia on plasma cortisol, scrotal circumference, growth, and feed intake of bull calves. J. Anim. Sci. 74:2336-2343(1996).

22) Fisher A. D., Knight T. W and Cosgrove G. P. Effects of surgical or banding castration on stress responses and behavior of bulls. Aust. Vet. J. 79:279-284(2001).

23) Tartakovsky B., De Baetselier P., Feldman M and Segal S. Sexassociated differences in the immune response against fetal major histocompatibility antigens. Transplantation, 32:395(1981).

24) Thomas M. E., Michael T. M., Phong T. L., Robert C. F and Eugene D.K. Alteration in peripheral $\mathrm{B}$ cells and $\mathrm{B}$ cell progenitors following androgen ablation in mice .Int. Immunol., 13(13)553558(2001). 
25) Goldberg R. B., Rabin D., Alexander A. N., Doelle G. C and Getz G. S. Suppression of plasma testosterone leads to an increase in serum total and high density lipoprotein cholesterol and apoproteins A-I and B. J Clin. Endocriol. Metab., 60:203-207(1985).

26) Casquero A.C., Berti J.A., Salerno A.G., Bighetti E.J.B., Cazita P. M., Ketelhuth D.F.J., Gidlund $\mathrm{M}$ and Oliveira C.H.F. Atherosclerosis is enhanced by testosterone deficiency and attenuated by CETP expression in transgenic mice. J. Lipid Res., 47; 1526-1534(2006).

27) Moorjanis S., Dupont A., Labrie F., Lupien P.J., Gangne C., Brun D., Gigurer M., Belanger A and Cusant L. Changes in plasma lipoproteins during various androgen suppression therapies in men with prostatic carcinoma: effect of orchiectomy, estrogen, and combination treatment with lutienizing hormone-releasing hormone agonist and flutamide. J. Clin. Endocinol. Metab., 66:314322(1988).

28) Briggs MR., Yokoyama C., Wang X., Brown MS and Goldstein JL. Nuclear protein that binds sterol regulatory element of low density lipoprotein receptor promoter.1. Identification of the protein and delination of its target nucleotide sequence J. Biol. Chem. 268:14490-14496(1996).

29) Wang X., Briggs MR., Hua X., Yokoyama C., Goldstein JL and Brown MS. Nuclear protein that binds sterol regulatory element of low density lipoprotein receptor promoter. 11.Purification and characterization .J. Biol. Chem., 268:14497-14504(1993).

30) Xu T., Wang X., Hou S., Zhu J., Zhang $X$ and Huang X. Effect of surgical castration on risk factor for arteriosclerosis of patients with prostate cancer. Clin. Med. J., 115:1336-1340(2003). 